\title{
Comparison of Corrosion Protection Efficiency of Two Kinds of Amino Acids
}

\author{
Albana Jano', Alketa Lame ${ }^{2}$, Efrosini Kokalari ${ }^{2}$ and Valbona Hoxha ${ }^{1}$ \\ ${ }^{1}$ Polytechnic University of Tirana, \\ Tirana/Albania \\ albana.jano@fin.edu.al,bonahoxha@gmail.com \\ ${ }^{2}$ University of Tirana \\ Tirana/Albania \\ Alketa.lame@fnsh.edu.al,efrosinikokalari@fshn.edu.al
}

\begin{abstract}
Corrosion is an inevitable natural phenomenon. The amino acids are green corrosion inhibitors due to their nontoxicity and biodegradability. For this reason they are a good choice for corrosion protection. As inhibitors, we have used two amino acids, lysine and methionine. They have shown good inhibitor properties in protection of low allow carbon steel against the corrosion in acidic media. The aim of this study is to compare corrosion protection efficiency of these amino acids. Material under investigation is low alloy carbon steel marked as: Steel 39, Steel 44 and the corrosion media is: $1 \mathrm{M} \mathrm{H}_{2} \mathrm{SO}_{4}+10^{-3} \mathrm{~mol} / \mathrm{L} \mathrm{Cl}^{-}$(in form of $\mathrm{NaCl}$ ). A Tafel polarization technique was used for investigation of corrosion inhibitor efficiency. The results present that methionine is more protective again acidic corrosion and the steel 44 is more sustainable again sulfuric acidic corrosion. The best case in the respect of corrosion sustainability for steel 44 is in presence of $1 \mathrm{~g} / \mathrm{L}$ methionine with protection efficiency respectively $81.27 \%$.
\end{abstract}

Keywords: amino acid, protection efficiency, carbon steel, Tafel polarization

\section{Introduction}

The high costs of corrosion have a significant effect on the national economy. Mild steel are the most commonly used construction materials due to its low cost, strength and ease of fabrication but they are affected greatly by its high corrosion rate caused by aggressive acids.(1) Reducing corrosion can be performed by the addition of corrosion inhibitors in small concentrations. Research on organic compounds reveals that compounds containing hetero atoms such as sulphur, phosphorous, nitrogen or oxygen and compounds containing double bonds and triple bonds inhibit corrosion of metal by surface adsorption.(2) The use of corrosion inhibitors with a minimal or zero negative effects is one of the most important practical methods for protection against corrosion.(3) Amino acids are environmentally friendly, non-toxic, biodegradable and relatively cheap. The main aim of our study is to compare the corrosion inhibition effect of methinine and lysine in sulfuric acid solution containing chloride ions in form of $\mathrm{NaCl}$ for equal concentration of two extracts. For this aim, potentiodynamic polarization technique was performed.

\section{Experimental}

Material under investigation are two marks of low alloy carbon steel, manufactured in KURUM factory, Elbasan, respectively St39, St44, intended for concrete armor. The mild steel electrode composition is: 
Table 1: Composition of low alloy carbon steel tested.

\begin{tabular}{|c|c|c|c|c|c|c|c|c|}
\hline 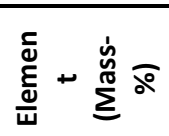 & C & $\mathrm{Si}$ & $M n$ & $\mathrm{Cr}$ & $\mathrm{Ni}$ & $\mathrm{Cu}$ & $\mathbf{P}$ & $S$ \\
\hline Steel 39 & 0.37 & 0.17 & 0.51 & 0.60 & 0.60 & 0.30 & 0.040 & 0.040 \\
\hline Steel 44 & 0.445 & 0.348 & 0.780 & 0.118 & 0.263 & 0.324 & 0.0720 & 0.0440 \\
\hline
\end{tabular}

The samples used for the potentiodynamic measurements are prepared from steel bars in cylindrical shape with sizes $(\mathrm{D}=6 \mathrm{~mm}, \mathrm{~d}=4 \mathrm{~mm})$ and fixed inside a Teflon tube with epoxy resin as shown in figure. Before the potentiodynamic measurements the surface of steel samples, before fixed inside the Teflon, were polished with emery paper $(250-1000)$, cleaned with be distilled water, dried, degreased with acetone, cleaned with be distilled water again, and finally dried.(4,5) Each experiment was performed with freshly prepared solution and a clean set of electrodes.

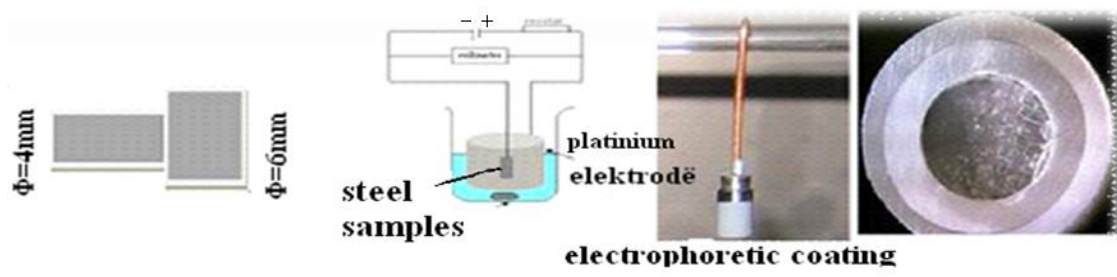

potentiodinamic method

Fig.1: Preparing of the samples for potentiodynamic measurements

The test solutions were in $1.0 \mathrm{M}$ sulfuric acid $+10^{-3} \mathrm{Cl}$ - solutions. Methionine and lysine were used as green inhibitors, whose chemical structures are given in figure.

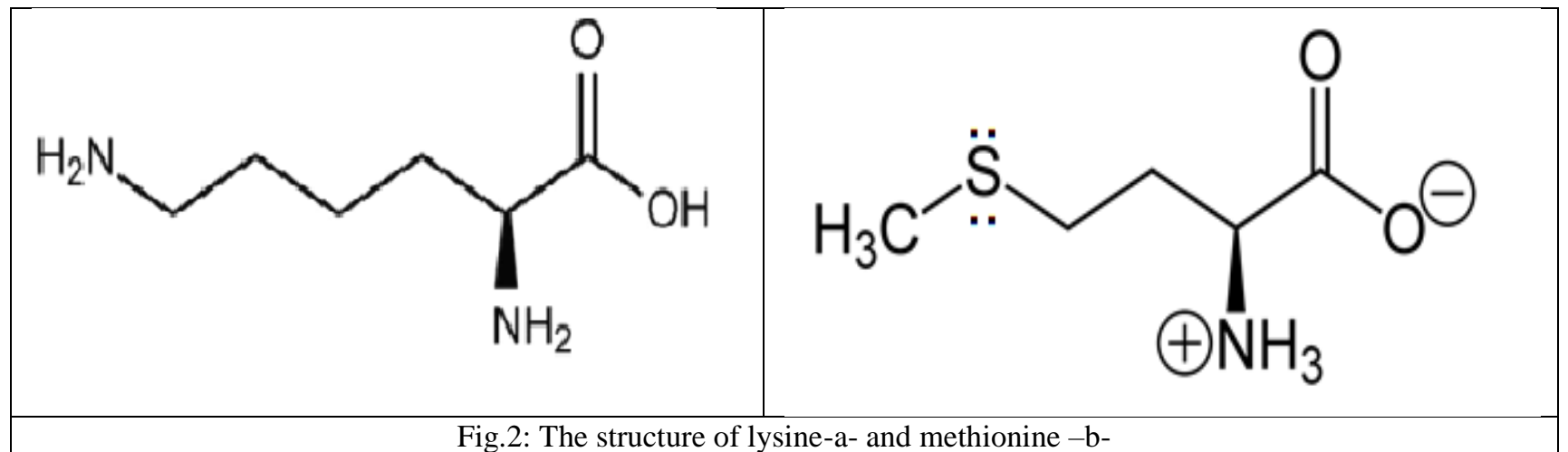

All tests were obtained in deaerated solutions. The concentration range of inhibitor employed was 0.75 and $1 \mathrm{~g} / \mathrm{L}$ as presented in Table 2. 
Table 2: The matrix for potenciodynamic measurements.

\begin{tabular}{|c|c|c|c|c|c|c|c|c|c|c|c|c|c|}
\hline \multirow{2}{*}{$\begin{array}{l}{[1]} \\
{[8]}\end{array}$} & \multirow[t]{2}{*}{$\mathrm{Nr}$} & \multirow{2}{*}{\multicolumn{2}{|c|}{$\begin{array}{c}\text { [2] }{ }^{\text {Blank }} \\
\text { [9] }\end{array}$}} & \multirow{2}{*}{\multicolumn{2}{|c|}{$\begin{array}{c}\text { [3] } 2^{\text {Blank }} \\
10]\end{array}$}} & \multirow{2}{*}{$\begin{array}{c}{[4]} \\
{[5]} \\
{[11]} \\
\end{array}$} & \multicolumn{3}{|c|}{$\begin{array}{l}\text { Concentrations of } \\
\text { methionine }(g / L)\end{array}$} & \multirow{2}{*}{$\begin{array}{c}{[6]} \\
{[7]} \\
{[13]}\end{array}$} & \multicolumn{3}{|c|}{$\begin{array}{l}\text { Concentrations } \\
\text { of } \\
\text { lysine }(\mathrm{g} / \mathrm{L})\end{array}$} \\
\hline & & & & & & & 0.75 & [12] & 1 & & 0.75 & [14] & 1 \\
\hline [15] & 1 & {$[16]$} & + & $\begin{array}{l}\text { [17] } \\
\end{array}$ & & [18] & & [19] & & {$[20]$} & & [21] & \\
\hline$[22]$ & 2 & [23] & & [24] & + & {$[25]$} & & {$[26]$} & & [27] & & [28] & \\
\hline [29] & 3 & [30] & + & [31] & & {$[32]$} & + & [33] & & {$[34]$} & & [35] & \\
\hline [36] & 4 & {$[37]$} & + & [38] & & [39] & & [40] & + & [41] & & [42] & \\
\hline$[43]$ & 5 & {$[44]$} & & {$[45]$} & + & {$[46]$} & & $\begin{array}{l}{[47]} \\
\end{array}$ & & $\begin{array}{l}48] \\
\end{array}$ & + & {$[49]$} & \\
\hline [50] & 6 & [51] & & [52] & + & [53] & & [54] & & [55] & & [56] & + \\
\hline
\end{tabular}

The measurements were carried out with a potentiostat/galvanostat. Electrochemical measurements were done using Potenciostat galvanostat tip TACUSSEL PJT 24-2. For this purpose, a conventional three-electrode cell was used, composed of $\mathrm{Hg} / \mathrm{Hg} 2 \mathrm{SO} 4$ saturated $\mathrm{K} 2 \mathrm{SO} 4$ reference electrode, a platinum electrode as auxiliary electrode, and the mild steel substrates as the working electrodes. The Potentiodynamic polarization curves were obtained by potencial scan rate $3 \times 10-2 \mathrm{~V} / \mathrm{min}$. $(6,4) \quad$ Deaerating of the solution was realized using a stream of pure nitrogen inside the solution for 30 min and above solution for $5 \mathrm{~min}$. Corrosion current density determined using the cutting point of Taffel extrapolation line and Faradays law, equation $1(4,6)$ :

$$
V_{\text {corr }}=(K * a * i) /(n * D)
$$

Where: $\mathrm{a}$ - is the atomic weight of the metal $(\mathrm{a}=56 \mathrm{~g} / \mathrm{mol}), \mathrm{i}$-the current density in $(\mu \mathrm{A} / \mathrm{cm} 2), \mathrm{n}$-the number of electrons exchanged during metal dissolution $(\mathrm{n}=2), \mathrm{D}$-the density in $(\mathrm{g} / \mathrm{cm} 3)(\mathrm{d}=7.86 \mathrm{~g} / \mathrm{cm} 3)$ and $\mathrm{K}$ is a constant which equals to 0.00327 if corrosion rate (Vcorr) is calculated in [mm/y]. Corrosion inhibitor efficiency calculated by formula 2 (7):

$$
\text { Inhibitor Efficiency }(\%)=[(\mathrm{CR} \text { uninhibited }-\mathrm{CR} \text { inhibited }) / \mathrm{CR} \text { uninhibited }] \mathrm{x} 100
$$

Where: CR uninhibited - is corrosion rate of the uninhibited system, CR inhibited - is corrosion rate of the inhibited system. This essentially examines the ratio of the inhibited and uninhibited corrosion rates and expresses this as a percentage.

\section{Results}

Potentiodynamic polarization curves and the corresponding average Tafel line for steel 39 (best case) with $78.88 \%$ protection efficiency in de-aerated $1 \mathrm{M} \mathrm{H}_{2} \mathrm{SO}_{4}$ solution, with $10^{-3} \mathrm{M}$ chloride ions in presence of $1 \mathrm{~g} / \mathrm{L}$ Lysine and for steel 44 (best case) with $81.27 \%$ protection efficiency in presence of $1 \mathrm{~g} / \mathrm{L}$ methionine, were presented in figures: 3 ; 4 , respectively. Figures 5, 6 represent the potentiodynamic polarization curves and the corresponding average Tafel line in presence of $0.75 \mathrm{~g} / \mathrm{L}$ respectively for steel 39 and steel 44 (the worst case with lower protection efficiency 54.31 and $34.44 \%$ ). 


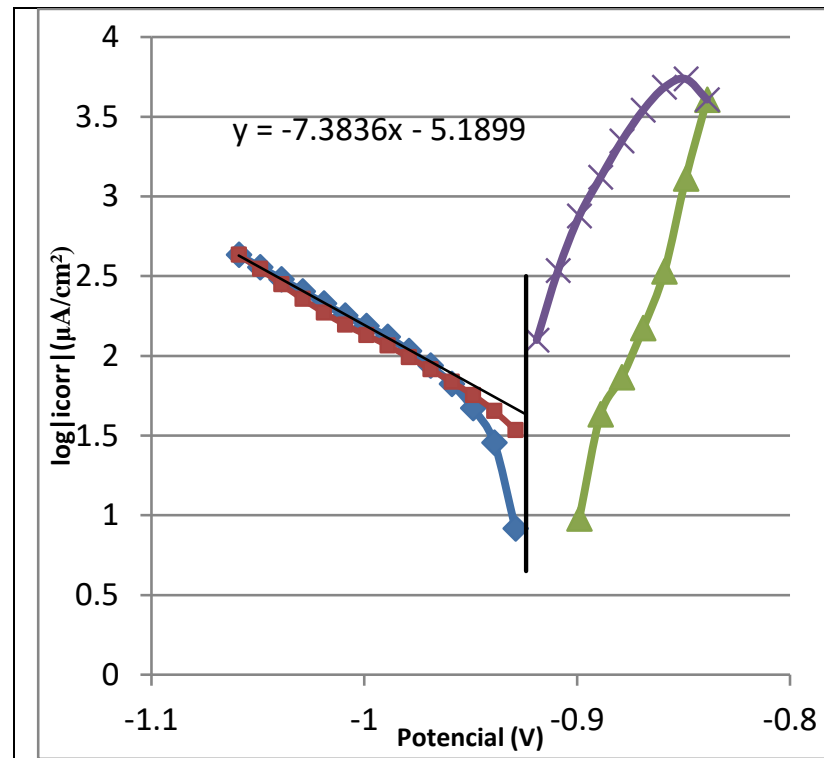

Fig.3: Potentiodynamic curves and Tafel extrapolations for Steel 39 in de-aerated $\mathrm{H}_{2} \mathrm{SO}_{4}$ solution with $10^{-3} \mathrm{M}$ chloride ions in presence of $1 \mathrm{~g} / \mathrm{L}$ lysine.

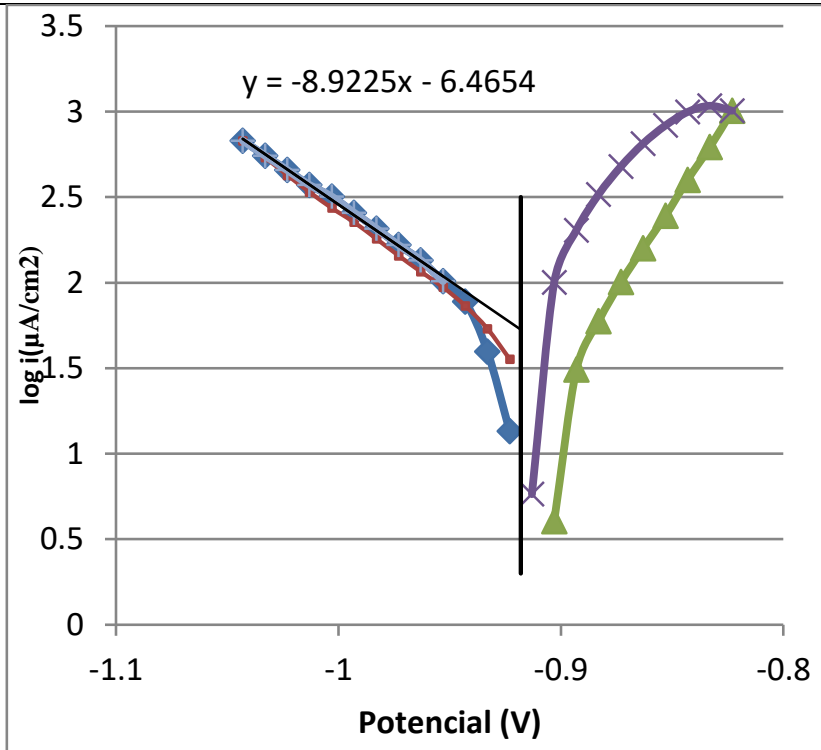

Fig.4: Potentiodynamic curves and Tafel extrapolations for Steel 44 in de-aerated $\mathrm{H}_{2} \mathrm{SO}_{4}$ solution with $10^{-3} \mathrm{M}$ chloride ions in presence of $1 \mathrm{~g} / \mathrm{L}$ methionine.

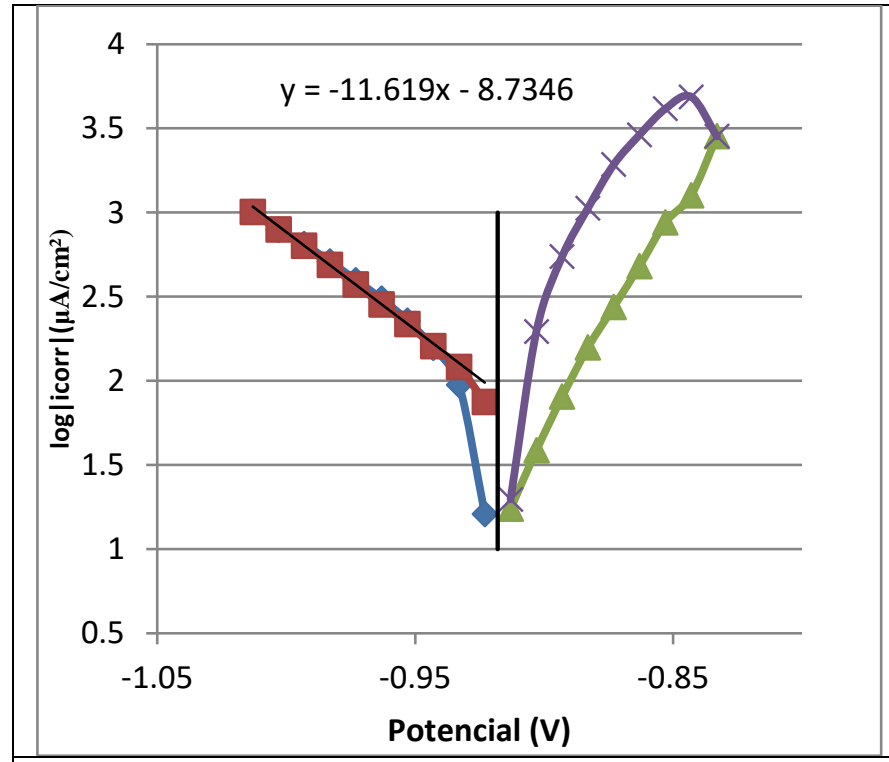

Fig.5: Potentiodynamic curves and Tafel extrapolations for Steel 39 in de-aerated $\mathrm{H}_{2} \mathrm{SO}_{4}$ solution with $10^{-3} \mathrm{M}$ chloride ions in presence of $0.75 \mathrm{~g} / \mathrm{L}$ lysine.

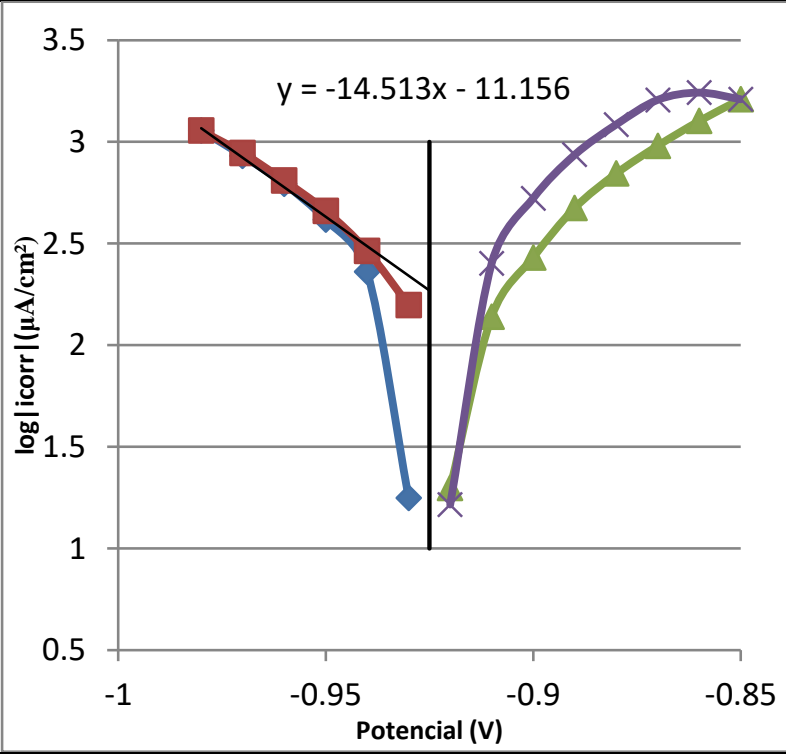

Fig.6: Potentiodynamic curves and Tafel extrapolations for Steel 44 in de-aerated $\mathrm{H}_{2} \mathrm{SO}_{4}$ solution with $10^{-3} \mathrm{M}$ chloride ions in presence of $0.75 \mathrm{~g} / \mathrm{L}$ lysine.

The results, in form of corrosion rates in ( $\mathrm{mm} /$ year), calculated using corrosion current density $\left(\mathrm{i}_{\text {corr }}\right)$ and protections efficiency of different concentration of additives against corrosion, are given in Table 3. 
Table 3: Corrosion rates and protection efficiency for St.44, St.39 in de-aerated $\mathrm{H}_{2} \mathrm{SO}_{4}$ solutions with $10^{-3} \mathrm{M}$ chloride ions (blank ) in presence of methionine and lysine.

\begin{tabular}{|c|c|c|c|c|c|c|c|c|c|}
\hline \multirow{3}{*}{$\begin{array}{c}\text { Mark of } \\
\text { steel } \\
\text { material }\end{array}$} & \multirow{3}{*}{ Blank } & \multicolumn{4}{|c|}{ Concentration methionine } & \multicolumn{4}{c|}{ Concentration of lysine } \\
\cline { 2 - 10 } & & \multicolumn{2}{|c|}{$0.75 \mathrm{~g} / \mathrm{L}$} & \multicolumn{2}{|c|}{$1 \mathrm{~g} / \mathrm{L}$} & \multicolumn{2}{c|}{$0.75 \mathrm{~g} / \mathrm{L}$} & \multicolumn{2}{c|}{$1 \mathrm{~g} / \mathrm{L}}$. \\
\cline { 2 - 10 } & $\begin{array}{c}\mathrm{V}_{\text {corr }} \\
\mathrm{mm} / \mathrm{y}\end{array}$ & $\begin{array}{c}\mathrm{V}_{\text {corr }} \\
\mathrm{mm} / \mathrm{y}\end{array}$ & $\begin{array}{c}\text { Prot. } \\
\text { Eff.\% }\end{array}$ & $\begin{array}{c}\mathrm{V}_{\text {corr }} \\
\mathrm{mm} / \mathrm{y}\end{array}$ & $\begin{array}{c}\text { Prot. } \\
\text { Eff. } \%\end{array}$ & $\begin{array}{c}\mathrm{V}_{\text {corr }} \\
\mathrm{mm} / \mathrm{y}\end{array}$ & $\begin{array}{c}\text { Prot. } \\
\text { Eff.\% }\end{array}$ & $\begin{array}{c}\mathrm{V}_{\text {corr }} \\
\mathrm{mm} / \mathrm{y}\end{array}$ & $\begin{array}{c}\text { Prot. } \\
\text { Eff.\% }\end{array}$ \\
\hline Steel 39 & 2.32 & 0.77 & 66.8 & 0.59 & 74.14 & 1.06 & 54.31 & 0.49 & 78.88 \\
\hline Steel 44 & 3.31 & 0.83 & 74.92 & 0.62 & 81.27 & 2.17 & 34.44 & 1.03 & 68.88 \\
\hline
\end{tabular}

\section{Discussion}

The inhibitive effect for most of the organic corrosion inhibitors was attributed to the accumulation of the inhibitor molecules by "direct" or/and "indirect" adsorption onto the metal surface, which reduces the contact of the metal with the corrosive agents in solution. (3) The corrosion potentials $\left(\mathrm{E}_{\mathrm{corr}}\right)$ of mild steel in presence of methionine and lysine were shifted toward less negative potentials, indicating enhancement in the corrosion resistance. Furthermore, it was observed that the corrosion current density $\left(\mathrm{I}_{\text {corr }}\right)$ in presence of the inhibitor was lower than that of corroded steel, confirming that both amino acids promoted corrosion resistance. The values of inhibition efficiency show a higher corrosion resistance of the inhibitors. The $\mathrm{E}_{\mathrm{corr}}$ as function of time data for methionine revealed that $\mathrm{E}_{\text {corr }}$ was shifted toward more positive value, while $\mathrm{i}_{\text {corr }}$ value was much lower than lysine and corroded steel. The positive shift of corrosion potential is evidently caused by the restriction of anodic reaction process. Corrosion rates were calculated to be 0.59 and $0.62 \mathrm{~mm} / \mathrm{year}$ for steel in presence of methionine $1 \mathrm{~g} / \mathrm{l}$ (best case), reflecting the corrosion resistance enhancement by replacing addition of amino acids.

In case of amino acids, specifically, methionine, used in our study as acidic corrosion inhibitor for low alloy carbon steel, the adsorption on anodic sites, dedicated the free electrons on S, N and $\mathrm{O}$ (of carboxylic group) atoms. S containing amino-acid interact in molecular form via the $\mathrm{S}$ atoms in aliphatic chain, which may be adsorbed at anodic sites and retard Fe electrochemical dissolution. This probably explains higher inhibition efficiency for S-containing amino acid.

The presence of $\mathrm{R}-\mathrm{S}-\mathrm{R}$ in molecular structure of methionine provokes an increase of the inhibition efficiency, which can be attributed to the fact that the sulfur containing amino acids can be adsorbed as bidentate ligands in which surface coordination is taking place through both the amino group (or carboxylic group) and the $-\mathrm{S}-$ moiety. $(8,9,3$ )

In the other hand, lysine adsorbs on surface of middle steel this mechanism: the atoms $\mathrm{O}$ and $\mathrm{N}$ in amino acids serve as active centers for the process of adsorption on the metal surface. Availability of no bonded (lone pair) and p-electrons in inhibitor molecules facilitate electron transfer from the inhibitor to the metal. A coordinate covalent bond involving transfer of electrons from inhibitor to the metal surface may be formed. The strength of the chemisorptions bond depends upon the electron density on the donor atom of the functional group and also the polarizability of the group. When an $\mathrm{H}$ atom attached to the $\mathrm{C}$ in the ring is replaced by a substituent group $\left(-\mathrm{NH}_{2}\right.$, or $\left.\mathrm{COOH}\right)$ it improves inhibition. (10)

\section{Conclusions}

Methionine mitigates the corrosion rate of the Steel 39 from: $2.32 \mathrm{~mm} /$ year $\div 0.59 \mathrm{~mm} /$ year with protection efficiency $74.14 \%$.

Methionine mitigates the corrosion rate of the Steel 44 from: $3.31 \mathrm{~mm} / \mathrm{year} \div 0.62 \mathrm{~mm} / \mathrm{year}$ with protection efficiency $81.27 \%$.

The steel 44 is more sustainable again sulfuric acidic corrosion and more sensitive versus presence of methionine, than steel 39. 


\section{References}

[1] Rasha A. Ahmed, Investigation of Corrosion Inhibition of Vitamins $B_{1}$ and C on Mild Steel in 0.5 M HCl Solution: Experimental and Computational Approach, Volume 32, Number 1

[2] A. Aloysius, R. Ramanathan, A. Christy, S. Baskaran, N. Antony, Experimental and theoretical studies on the corrosion inhibition of vitamins - Thiamine hydrochloride or biotin in corrosion of mild steel in aqueous chloride environment, June 2017Egyptian Journal of Petroleum 27(3) DOI:10.1016/j.ejpe.2017.06.003

[3] B. El Ibrahimi, A. Jmiai, L.Bazzi, S.El Issami, Amino acids and their derivatives as corrosion inhibitors for metals and alloys, Volume 13, issue 1, January 2020, Pages 740-771

[4] M. G. Fontana, Corrosion Engineering, Third Edition, ISBN 0-07-021463-8, Printed in the United States of America, 1986, 171-174; 153-164; 198-202; 172.

[5] 5.M. Abdallah, Guar Gum as Corrosion Inhibitor for Carbon Steel in Sulfuric Acid Solutions, Portugaliae Electrochimica Acta 22, 2004, 161-175.

[6] E. Bardal, Engineering Materials and Processes, Corrosion and Protection, Springer-Verlag limited ISBN 1855233-758-3, London Berlin Heidelberg, 2004,5-10.

[7] E. G. Azero, L. L. Lopes, C. T. Andrade, Extraction and Solution Properties of the Galactomannan from the Seeds of Cassia-Javanica L, Polymer Bulletin 39, 1997,621 - 625.

[8] A.Jano, A. Lame, E. Kokalari, 2014, The Inhibition Effects Of Methionine On Mild Steel In Acidic Media, Seria: Chimie, Ovidius University Annals Of Chemistry, Vol.XXV Year XXV - 2014, Number 1, ISSN:1223-7221.

[9] A.Lame, E. Kokalari, A. Jano, Migration Corrosion Inhibitor Agains Premature Failure Of Reinforced Concrete Caused By Penetration Of Aggressive Environment, International Journal Of Ecosystems And Ecology Science (IJEES), 2014, ISSN: 2224-4980, Volume 4/3, page 491-498.

[10] 10. A. Jano, A.Lame, E. Kokalari, Lysine As A Corrosion Inhibitor For Low Alloy Carbon Steel In Acidic Media, 2014, Seria: Chimie, Ovidius University Annals Of Chemistry, Vol.XXV Year XXV - 2014, Number 1, ISSN:1223-7221. 